\title{
PENERAPAN MODEL PEMBELAJARAN INKUIRI TERBIMBING UNTUK MENINGKATKAN KEMANDIRIAN DAN PRESTASI BELAJAR PADA MATERI REAKSI REDOKS SISWA KELAS X MIPA SMA NEGERI 1 TERAS BOYOLALI TAHUN PELAJARAN 2016/2017
}

\author{
Julaikha Rizki Puspitasari, Ashadi ${ }^{\star}$, dan Agung Nugroho Catur Saputro
}

Program Studi Pendidikan Kimia, FKIP,Universitas Sebelas Maret, Surakarta, Indonesia

*Keperluan korespondensi, HP 0816671690, e-mail: ashadiuns2014@gmail.com

\begin{abstract}
ABSTRAK
Tujuan penelitian ini adalah (1) meningkatkan kemandirian siswa pada materi reaksi redoks melalui model pembelajaran inkuiri terbimbing (2) meningkatkan prestasi belajar siswa pada materi reaksi redoks melalui model pembelajaran inkuiri terbimbing. Sebanyak 35 orang siswa kelas X MIPA 4 SMA Negeri 1 Teras Boyolali berpartisipasi dalam penelitian yang dilakukan pada dua siklus. Masing-masing siklus pembelajaran terdiri dari tahap perencanaan, pelaksanaan tindakan, hasil tindakan, dan refleksi. Data pada setiap siklus diperoleh melalui tes, angket penilaian diri, observasi, dokumentasi, dan wawancara. Hasil pelaksanaan tindakan menunjukkan bahwa penerapan model pembelajaran inkuiri terbimbing mampu meningkatkan kemandirian dan prestasi belajar siswa. Kemandirian belajar siswa pada siklus I sebesar 68,52\%, siklus II meningkat menjadi 78,7\%. Prestasi belajar aspek pengetahuan pada siklus I sebesar 41,67\% dan siklus II meningkat menjadi 63,89\%. Aspek sikap dan aspek keterampilan telah mencapai target pada siklus I yaitu dengan ketercapaian sebesar $90 \%$ untuk aspek sikap dan ketercapaian sebesar $100 \%$ untuk aspek keterampilan. Hal ini menunjukkan bahwa penerapan model pembelajaran inkuiri terbimbing dapat meningkatkan kemandirian dan prestasi belajar siswa.
\end{abstract}

Kata kunci: inkuiri terbimbing, kemandirian, prestasi belajar, redoks.

\section{PENDAHULUAN}

Indonesia merupakan negara besar yang memiliki ketersediaan sumber daya alam dan manusia melimpah. Hal ini diharapkan dapat menjadikan Indonesia sebagai negara mandiri dalam mengolah hasil alam. Dalam mewujudkan Indonesia mandiri maka dibutuhkan sumber daya manusia yang berkualitas agar semua hasil alam dapat terolah dengan baik. Melalui pendidikan maka manusia akan memiliki kecerdasan dan kemampuan diri untuk menjadi manusia yang berkualitas. Berdasarkan UUD 1945 pasal 31 ayat 1, menyatakan bahwa Setiap warga negara berhak mendapat pendidikan [1]. Salah satu upaya pemerintah untuk mewujudkannya yaitu dengan menerapkan pendidikan wajib 9 tahun yang tertuang dalam UU No. 20 Tahun 2003 Pasal 6 yang menyebutkan bahwa setiap warga negara yang berumur 7 sampai 15 tahun wajib mengikuti pendidikan dasar [2].

Pendidikan sebagai usaha sadar dan terencara baik dalam lingkup nasional, regional/provinsi dan kabupaten kota, institusional/sekolah maupun operasional (proses pembelajaran). Perencanaan proses pembelajaran sesuai dengan silabus dan Rencana Perangkat Pembelajaran untuk mewujudkan suasana belajar dan proses pembelajaran yang nyaman dan kondusif agar siswa dapat mengembangkan potensi dirinya secara aktif sesuai dengan tujuan pendidikan nasional. Proses pembelajaran dilaksanakan sesuai dengan kurikulum yang berlaku di sekolah tersebut. Kurikulum yang diterapkan saat ini yaitu kurikulum 2013. Kurikulum 2013 memiliki capaian untuk siswa dalam ranah pengetahuan, 
keterampilan, dan sikap. Di dalam pelaksanaannya proses pembelajaran berpusat pada siswa (student centered) sehingga diharapkan siswa berperan aktif dan mandiri dalam menkonstruksikan pengetahuan yang diperolehnya. Kemandirian belajar siswa mencakup beberapa indikator, antara lain: sikap mental yang positif, memiliki inisiatif, dan percaya diri. Apabila siswa mandiri, maka siswa tersebut akan mampu untuk mengembangkan potensi dirinya menjadi pribadi yang berkualitas dan terampil dalam menerapkan ilmu pengetahuannya di kehidupan sesuai dengan tujuan pendidikan nasional.

Salah satu mata pelajaran yang dipelajari di sekolah menengah atas adalah kimia. IImu kimia adalah ilmu yang mempelajari tentang jawaban atas pertanyaan apa, mengapa, dan bagaimana fenomena alam yang berkaitan dengan komposisi, struktur dan sifat, dinamika, dan energetik zat yang melibatkan keterampilan dan penalaran [3]. Kimia merupakan salah satu cabang IPA yang khusus mempelajari komposisi, struktur, sifat, perubahan dan energi yang menyertai perubahan materi. Oleh sebab itu, dalam mempelajari ilmu kimia diperlukan kedisiplinan dan metode penyelidikan (metode inkuiri) yang meliputi bagaimana cara berpikir dan bernalar, merumuskan masalah, melakukan percobaan dan mengumpulkan data, menganalisis data serta menyimpulkan untuk memperoleh produk-produk sains.

SMA Negeri 1 Teras Boyolali merupakan salah satu sekolah tingkat menengah atas di Kabupaten Boyolali yang menerapkan kurikulum 2013. Di dalam pelaksanaan proses pembelajaran Kurikulum 2013 seharusnya berpusat pada siswa (student centered) namun masih sering berpusat pada guru (teacher centered). Berdasarkan hasil observasi pada bulan Desember 2016Januari 2017, angket penilaian diri dan wawancara dengan guru kimia kelas $X$ MIPA yaitu Ibu Esti Putriyanti, peneliti dapat mengidentifikasi beberapa masalah di sekolah.
Tabel 1. Data Ketuntasan Siswa UTS dan UAS Tahun Pelajaran 2016/2017 semester ganjil

\begin{tabular}{lcc}
\hline \multirow{2}{*}{ Kelas } & \multicolumn{2}{c}{ Ketuntasan (\%) } \\
\cline { 2 - 3 } & UTS & UAS \\
\hline X MIPA 3 & 49 & 77 \\
X MIPA 4 & 54 & 53 \\
\hline
\end{tabular}

Berdasarkan ketuntasan belajar siswa mata pelajaran kimia pada saat UTS dan UAS yang ditunjukkan pada Tabel 1 [4] dapat diketahui bahwa prestasi belajar siswa pada kelas X MIPA 4 lebih rendah daripada kelas X MIPA 3. Pada materi kimia kelas $X$ semester 2 yang dianggap sulit oleh siswa yaitu materi reaksi redoks. Indikator kompetensinya yaitu Menentukan zat yg mengalami reaksi autoredoks/bilangan oksidasi serta bilangan oksidasinya dari suatu reaksi autoredoks. Hal ini ditunjukkan pada Tabel 2 dari ketuntasan siswa SMA Negeri 1 Teras Boyolali pada Ujian Nasional tahun pelajaran 2015/2016 [5].

Tabel 2. Ketuntasan Siswa SMA Negeri

1 Teras Boyolali pada UN 2015/2016

Ketuntasan (\%)

Sekolah Kota/Kab. Propinsi Nasional

$24,53 \quad 28,78 \quad 29,49 \quad 46,40$

Indikator kompetensi tersebut terkait materi reaksi reduksi dan oksidasi. Berdasarkan Permendikbud No. 24 Tahun 2016, materi Reaksi Redoks mempunyai Kompetensi Dasar yakni (1) Menentukan bilangan oksidasi unsur untuk mengidentifikasi reaksi reduksi dan oksidasi serta penamaan senyawa (2) Membedakan reaksi yang melibatkan dan tidak melibatkan perubahan bilangan oksidasi melalui percobaan [6].

Di dalam proses pembelajaran kimia, siswa masih bergantung pada guru, sehingga hanya terjadi komunikasi satu arah dan berpusat pada guru. Oleh sebab itu dapat dikatakan bahwa masih kurangnya sikap kemandirian siswa dalam proses pembelajaran yang 
meliputi 3 aspek yaitu: memiliki inisiatif, sikap mental yang positif dan percaya diri. Kurangnya kemandirian siswa dibuktikan dari hasil angket penilaian diri aspek kemandirian, yaitu $X$ MIPA 4 sebesar $61,11 \%$ dan X MIPA 3 sebesar $77,14 \%$. Berdasarkan data tersebut dapat dinyatakan bahwa rata-rata siswa di kelas X MIPA 4 memiliki kemandirian yang lebih rendah dibandingkan dengan rata-rata siswa di kelas X MIPA 3.

Berdasarkan uraian di atas dapat diketahui bahwa permasalahan yang terjadi di kelas X MIPA 4 SMA Negeri 1 Teras Boyolali memerlukan suatu tindakan untuk meningkatkan kemandirian dan prestasi belajar siswa kelas $X$ MIPA 4 SMA Negeri 1 Teras Boyolali melalui model pembelajaran.

Salah satu model pembelajaran yang dapat diterapkan dalam kurikulum 2013 yaitu model pembelajaran inkuiri. Pembelajaran inkuiri terbagi menjadi tiga, yaitu inkuiri bebas, inkuiri terbimbing dan inkuiri bebas termodifikasi. Inkuiri terbimbing merupakan salah satu model pembelajaran yang melibatkan siswa dalam prosesnya untuk memecahkan suatu masalah secara mandiri. Sintaks Pembelajaran inkuiri terbimbing antara lain: penjelasan prosedur penelitian oleh guru, penyajian masalah oleh guru, perumusan hipotesis oleh siswa dengan bimbingan guru, pengumpulan data dengan bimbingan guru, analisis data oleh siswa dengan bimbingan guru, penarikan kesimpulan oleh siswa dengan bimbingan berupa pertanyaanpertanyaan oleh guru, dan mengkomunikasikan dalam bentuk laporan [7]. Hal ini dikarenakan pada proses pembelajaran inkuiri terbimbing berpusat pada siswa dengan bimbingan guru dalam aktivitas siswa.

Pada penelitian Karyatin (2013), penerapan pembelajaran inkuiri terbimbing mengalami peningkatan hasil belajar IPA dengan nilai rata-rata siklus I sebesar 75,00 menjadi 79,00 pada siklus II [8]. Sejalan dengan penelitian Schwarz dan Gwekwerere (2006) bahwa terjadi peningkatan yang signifikan dalam post test dari rencana pembelajaran, hal ini dikarenakan pembelajaran siswa yang berorientasi pada penemuan [9].
Menurut. Villagonzalo (2014) bahwa siswa memperoleh hasil yang tinggi dalam memecahkan masalah dan pemahaman pada penerapan model inkuiri terbimbing [10]. Sejalan dengan penelitian Barthlow (2011) yang menyatakan bahwa model pembelajaran inkuiri terbimbing efektif untuk meningkatkan prestasi belajar siswa dan dapat mengatasi kesenjangan prestasi siswa dalam proses pembelajaran melibatkan siswa dalam melakukan penyelidikan dan dapat membantu siswa dalam memahami konsep yang bersifat abstrak [11].

Berdasarkan latar belakang di atas, maka dilakukan penelitian yang dimaksudkan untuk meningkatkan kemandirian dan prestasi belajar siswa dengan penerapan model pembelajaran Inkuiri Terbimbing. Penelitian tersebut dituangkan dalam sebuah judul "Penerapan Model Pembelajaran Inkuiri Terbimbing untuk Meningkatkan Kemandirian dan Prestasi Belajar pada Materi Reaksi Redoks Siswa Kelas X MIPA SMA Negeri 1 Teras Boyolali Tahun Pelajaran 2016/2017 Semester Genap".

\section{METODE PENELITIAN}

Penelitian ini adalah Penelitian Tindakan Kelas (PTK) yang dilaksanakan dalam dua siklus, dimana masingmasing siklus terdapat empat tahapan yaitu 1) perencanaan tindakan, 2) pelaksanaan tindakan, 3) observasi dan interpretasi, dan 4) analisis dan refleksi tindakan [12]. Data penelitian ini meliputi data prestasi belajar siswa yang mencakup aspek pengetahuan, aspek sikap serta aspek keterampilan dan data kemandirian belajar siswa. Subyek dalam penelitian ini adalah siswa kelas $X$ MIPA 4 SMA Negeri 1 Teras Tahun Pelajaran 2016/2017 Semester 2 yang terdiri dari 36 siswa.

Data penelitian meliputi aspek pengetahuan, aspek sikap, aspek keterampilan dan kemandirian belajar. Teknik pengumpulan data melalui tes dan non-tes (observasi, angket, wawancara, dan kajian dokumen). 
Instrumen pembelajaran meliputi silabus dan rencana pelaksanaan pembelajaran (RPP). Instrumen penilaian meliputi instrumen penilaian aspek pengetahuan, aspek sikap, aspek keterampilan dan kemandirian belajar. Teknik analisis instrumen aspek pengetahuan menggunakan uji validitas, reliabilitas, uji tingkat kesukaran dan uji daya pembeda. Sedangkan untuk instrumen penilaian aspek sikap, aspek keterampilan dan kemandirian belajar menggunakan uji validitas dan uji reliabilitas.

Data dari hasil penelitian diolah dan dianalisis secara deskriptif kualitatif. Teknik analisis kualitatif mengacu pada model analisis Miles dan Huberman [13]. Teknik analisis data secara kualitatif mengacu pada model analisis yang dilakukan dalam tiga komponen yaitu reduksi data, penyajian data, dan penarikan kesimpulan serta verifikasi.

Teknik yang diperlukan untuk memeriksa validitas data yang digunakan dalam penelitian ini adalah triangulasi. Triangulasi adalah teknik pemeriksaan keabsahan data yang memanfaatkan sesuatu yang lain diluar data itu untuk keperluan pengecekan atau sebagai pembanding terhadap data ini [14]. Dalam penelitian ini, peneliti menggunakan teknik triangulasi metode yang dilakukan dengan cara membandingkan informasi atau data yang diperoleh melalui teknik observasi, angket dan wawancara.

\section{HASIL DAN PEMBAHASAN}

Penelitian tindakan yang dilakukan terdiri dari dua siklus. Setiap siklus dilakukan diskusi antara peneliti dan guru dalam merencanakan pembelajaran mengenai RPP dan skenario tindakan menggunakan model pembelajaran inkuiri terbimbing.

\section{Pratindakan}

Pratindakan penelitian dilakukan dengan wawancara dan observasi pada 7 Januari 2017 dengan guru mata pelajaran kimia kelas $X$ yaitu Ibu Esti Putriyanti S.Pd. yang bertujuan untuk mengetahui permasalahan siswa selama pembelajaran di kelas. Berdasarkan hasil observasi diperoleh informasi bahwa selama pembelajaran siswa bergantung kepada guru.

Siswa cenderung pasif kurang antusias, saat diberikan soal yang lebih sulit selalu mengeluh, siswa kurang inisiatif dan kurangnya rasa percaya diri juga ditunjukkan oleh siswa didalam kelas

Berdasarkan hasil dari angket prasiklus antara kelas X MIPA 3 dan X MIPA 4 SMA N 1 Teras Boyolali diperoleh data seperti pada Tabel 3 Kemandirian siswa yang diujikan pada angket prasiklus meliputi 3 aspek yaitu: memiliki inisiatif, sikap mental yang positif dan percaya diri.

Tabel 3 Hasil Angket Prasiklus Kemandirian Kelas MIPA

\begin{tabular}{ccc}
\hline Kelas & Tuntas (\%) & Tidak tuntas (\%) \\
\hline X MIPA 3 & 77,14 & 22,86 \\
X MIPA 4 & 61,11 & 38,89 \\
\hline
\end{tabular}

Berdasarkan uraian diatas, dapat diidentifikasi bahwa permasalahan siswa Kelas X MIPA 4 SMA N 1 Teras adalah rendahnya kemandirian siswa dan prestasi belajar. Guru dapat mengatasinya dengan memilih model pembelajaran yang sesuai dengan tujuan dan karakter siswa. Salah satu model pembelajaran yang dapat digunakan yaitu inkuiri terbimbing, karena siswa akan memperoleh penemuan oleh siswa sendiri sehingga pembelajaran akan lebih bermakna dan diingat oleh siswa. Oleh sebab itu, dalam pembelajarannya dilengkapi oleh Lembar Kerja Siswa (LKS) yang berisi instruksi dan arahan mempelajari materi reaksi redoks.

\section{Siklus I}

Siklus I dilaksanakan dengan 3 pertemuan yaitu pada tanggal 7,14 dan 21 Februari 2017. Pembelajaran pada siklus I direncanakan sebanyak 6 JP untuk proses pembelajaran dan $1 \mathrm{JP}$ untuk evaluasi. Perencanaan tindakan pada siklus I meliputi penyusunan instrumen pembelajaran dan instrumen penilaian. Instrumen pembelajaran 
meliputi silabus, Rencana Pelaksanaan Pembelajaran (RPP), dan media pembelajaran (LKS). Silabus yang digunakan peneliti adalah silabus dari sekolah yang disusun sesuai dengan kurikulum 2013. Sedangkan RPP yang digunakan adalah RPP yang dibuat oleh peneliti bersama guru mata pelajaran kimia sesuai dengan silabus dan model pembelajaran yang akan digunakan (model pembelajaran inkuiri terbimbing). Media pembelajaran yang digunakan pada penelitian ini adalah Lembar Kerja Siswa (LKS) yang dibuat oleh peneliti bersama guru mata pelajaran kimia. Instrumen penilaian meliputi penilaian aspek pengetahuan serta lembar observasi dan angket penilaian diri untuk kemandirian belajar, sikap, dan keterampilan.

\section{Siklus II}

Pada siklus II berdasarkan hasil refleksi dari siklus I, peneliti merencanakan tindakan yang akan dilakukan pada siklus II bersama guru. Tindakan siklus II dilaksanakan dalam 2 kali pertemuan yaitu 1 kali pertemuan untuk menyampaikan materi dan 1 kali pertemuan untuk evaluasi siklus II. Pertemuan pertama pada siklus II yang dilaksanakan pada 28 Februari 2017 dan pertemuan kedua pada siklus II dilaksanakan pada 14 Maret 2017.

Perbaikan yang direncanakan untuk pembelajaran siklus II disusun pada RPP yang difokuskan pada materi yang indikator kompetensinya tidak mencapai target. Indikator kompetensi yang belum tercapai pada siklus I yaitu indikator kompetensi mengidentifikasi reaksi reduksi dan oksidasi. Selain itu, perbaikan juga dilakukan pada pembagian kelompok dalam proses pembelajaran di siklus II yaitu dengan anggota 4 siswa setiap kelompoknya. $\mathrm{Hal}$ ini bertujuan agar siswa lebih aktif, kondusif dan semua anggota mengerjakan tugas dengan fokus. Dalam pembagian kelompok memperhatikan dari hasil tes aspek pengetahuan pada sikllus I agar penyebaran siswa lebih merata. Pada siklus II, LKS yang digunakan juga diperbaiki sesuai dengan indikator kompetensi yang akan di sampaikan. Guru lebih menekankan pada siswa agar lebih banyak berlatih soal dan menggunakan buku referensi kimia dalam menyelesaikan permasalahan yang ada dalam LKS di siklus II.

\section{Kemandirian Belajar Siklus I dan II}

Berdasarkan hasil penilaian kemandirian belajar siswa yang dilakukan pada siklus I dan siklus II melalui angket penilaian diri, observasi serta wawancara dapat dilihat pada Gambar 1 yang menunjukkan bahwa terjadi peningkatan kemandirian belajar siswa dari siklus I ke siklus II.

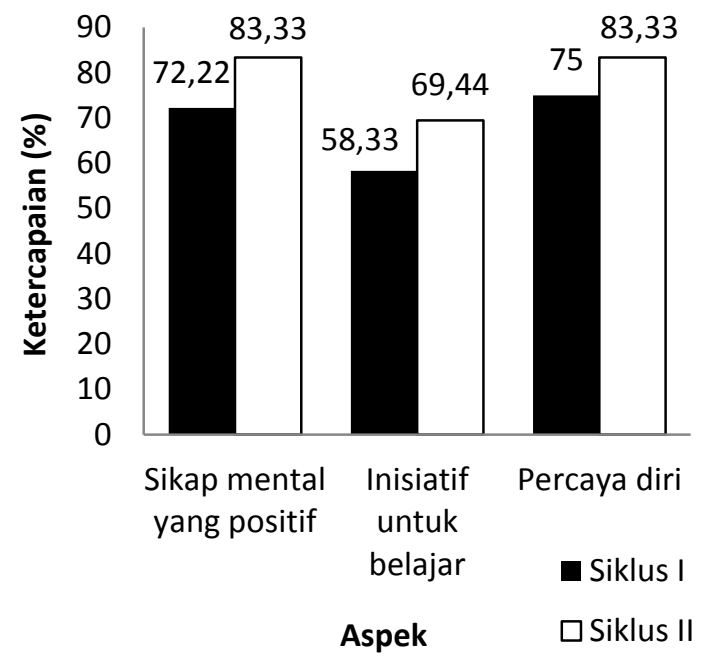

Gambar 1 Histogram peningkatan penilaian kemandirian siklus I dan II

Berdasarkan Gambar 1 dapat diketahui bahwa indikator sikap mental yang positif pada siklus I sebesar $72,22 \%$ mengalami peningkatan $11,11 \%$ pada siklus II menjadi $83,33 \%$. Indikator memiliki inisiatif diri untuk belajar pada siklus I sebesar $58,33 \%$ mengalami peningkatan sebesar $11,11 \%$ pada siklus II menjadi 69,44\%. Indikator Percaya diri pada siklus I sebesar $75 \%$ mengalami peninngkatan sebesar $8,33 \%$ pada siklus II menjadi 83,33\%.

Peningkatan kemandirian belajar siswa tidak mengalami kenaikan signifikan, hal ini dikarenakan masih rendahnya inisiatif diri untuk belajar pada siswa yang berdampak pada sikap mental yang positif dan percaya diri pada siswa. Penilaian kemandirian belajar 
siswa siklus I dan siklus II dapat dilihat pada Tabel 4.

Tabel 4. Penilaian Kemandirian Belajar Siklus I dan Siklus II

\begin{tabular}{|c|c|c|}
\hline \multirow{2}{*}{ Ketuntasan } & \multicolumn{2}{|c|}{ Ketercapaian (\%) } \\
\hline & Siklus I & Siklus II \\
\hline Tuntas & \begin{tabular}{l}
\multicolumn{6}{c}{$\mathbf{6 8 , 5 2}$} \\
(22,22 Sangat \\
Mandiri dan \\
46,3 Mandiri)
\end{tabular} & \begin{tabular}{l}
\multicolumn{2}{c}{$\mathbf{2 8 , 7}$} \\
(33,33 Sangat \\
Mandiri dan \\
45,37 Mandiri)
\end{tabular} \\
\hline $\begin{array}{l}\text { Tidak } \\
\text { Tuntas }\end{array}$ & \begin{tabular}{lr}
\multicolumn{2}{c}{$\mathbf{3 1 , 4 8}$} \\
$(27,31$ & Cukup \\
Mandiri & dan \\
$4,17 \quad$ Kurang \\
Mandiri)
\end{tabular} & \begin{tabular}{l}
\multicolumn{2}{c}{$\mathbf{2 1 , 3}$} \\
$(18,52$ Cukup \\
Mandiri dan \\
2,78 Kurang \\
Mandiri)
\end{tabular} \\
\hline
\end{tabular}

Peningkatan tersebut disebabkan oleh beberapa faktor yang meliputi penggunaan model pembelajaran inkuiri terbimbing dan penggunaan media LKS dalam pembelajaran. Pertama, penggunaan model inkuiri terbimbing dalam pembelajaran memiliki beberapa tahap yang menunjang peningkatan kemandirian belajar siswa.

Hal ini sesuai dengan Sari (2016) yang menyatakan bahwa apabila kepercayaan diri siswa meningkat, siswa menjadi tidak lagi bergantung kepada orang lain dan secara otomatis kemandirian belajar siswapun akan meningkat [15]. Pamungkas (2013) pada penelitiannya yang menyimpulkan bahwa penerapan strategi inkuiri terbimbing dapat meningkatkan kemandirian dan hasil belajar siswa. Kemandirian siswa ditunjukkan dengan kepercayaan diri siswa [16], ketergantungan siswa dengan teman setelah dilakukan tindakan mengalami peningkatan. Kedua, penggunaan media LKS yang berbasis inkuiri di dalam pembelajaran yang berfungsi untuk mempermudah siswa memahami konsep materi dan meminimalisir peran guru dalam aktivitas siswa menemukan konsep.

Berdasarkan penelitian Brown (2010), belajar dalam kelompok memungkinkan siswa untuk lebih mengembangkan penalaran ke tingkat yang lebih tinggi [17]. Sehingga siswa dapat mengembangkan inisiatifnya dalam menemukan konsep reaksi redoks dengan arahan-arahan yang ada pada LKS. Sari (2016) menyatakan bahwa LKS berbasis inkuiri berfungsi untuk memberikan arahan kepada siswa dan mendorong terjadinya student centered learning dalam kegiatan pembelajaran [15]. Sejalan dengan Setiowati (2015) menyatakan bahwa LKS berbasis inkuiri mampu menuntut siswa untuk aktif bekerjasama dengan kelompoknya serta menuntut siswa untuk mandiri baik secara individu maupun kelompok dalam menemukan konsep dan memecahkan soal. Sehingga siswa dapat secara mandiri untuk menemukan konsep materi [18].

\section{Aspek Pengetahuan}

Ketercapaian indikator kompetensi aspek pengetahuan siklus I dan Siklus II disajikan pada Tabel 5.

Tabel 5. Hasil Ketercapaian Indikator Kompetensi Aspek Pengetahuan Siklus I dan Siklus II

\begin{tabular}{|c|c|c|c|c|}
\hline \multirow{2}{*}{ Indikator Kompetensi } & \multirow{2}{*}{$\begin{array}{c}\text { Target } \\
(\%)\end{array}$} & \multicolumn{2}{|c|}{ Ketercapaian (\%) } & \multirow{2}{*}{ Kriteria } \\
\hline & & Siklus I & Siklus II & \\
\hline $\begin{array}{l}\text { Menjelaskan pengertian } \\
\text { reaksi reduksi oksidasi }\end{array}$ & 60 & 70,56 & $\begin{array}{c}\text { Tidak dilakukan } \\
\text { penilaian pada siklus II }\end{array}$ & Tercapai \\
\hline $\begin{array}{l}\text { Mengidentifikasi reaksi } \\
\text { reduksi dan oksidasi }\end{array}$ & 60 & 37,9 & 69,91 & Tercapai \\
\hline $\begin{array}{l}\text { Menentukan bilangan } \\
\text { oksidasi suatu unsur } \\
\text { Membedakan reaksi yang }\end{array}$ & 60 & 63,88 & $\begin{array}{c}\text { Tidak dilakukan } \\
\text { penilaian pada siklus II }\end{array}$ & Tercapai \\
\hline $\begin{array}{l}\text { melibatkan perubahan } \\
\text { bilangan oksidasi dan tidak } \\
\text { melibatkan perubahan } \\
\text { bilangan oksidasi }\end{array}$ & 60 & 62,96 & $\begin{array}{c}\text { Tidak dilakukan } \\
\text { penilaian pada siklus II }\end{array}$ & Tercapai \\
\hline
\end{tabular}


Berdasarkan ketuntasan prestasi belajar siswa aspek pengetahuan yang disajikan pada Tabel 6 menunjukkan bahwa terjadi peningkatan dari siklus I ke siklus II. Ketuntasan belajar siswa aspek pengetahuan dari siklus I ke siklus II meningkat sebesar $22,22 \%$.

Tabel 6 Hasil Ketuntasan Belajar Siswa Aspek Pengetahuan Siklus I dan II

\begin{tabular}{cccc}
\hline \multirow{2}{*}{ Aspek } & \multirow{2}{*}{$\begin{array}{c}\text { Target } \\
(\%)\end{array}$} & \multicolumn{2}{c}{ Ketuntasan (\%) } \\
\cline { 3 - 4 } & \multicolumn{2}{c}{ Siklus I } & Siklus II \\
\hline Pengetahuan & 60 & 41,67 & 63,89 \\
\hline
\end{tabular}

\section{Aspek Sikap}

Penilaian aspek sikap meliputi aspek sikap spiritual dan sikap sosial (jujur, disiplin, tanggungjawab dan kerjasama). Siswa yang mencapai ketuntasan penilaian aspek sikap ditunjukkan dengan perolehan skor siswa minimal 3 (kategori baik) pada siklus I sebesar 90\%. Berdasarkan Permendikbud No. 104 penilaian sikap digolongkan menjadi 4 kategori antara lain: Sangat Baik (SB), Baik (B), Cukup (C), dan Kurang (K) [19]. Pengkategorian nilai akhir siswa pada aspek sikap yaitu siswa dengan kategori Sangat Baik sebesar 47,78\% dan kategori Baik sebesar $42,22 \%$. Sedangkan siswa yang belum tuntas (Kategori Cukup dan Kurang) sebesar $10 \%$.

\section{Aspek Keterampilan}

Aspek keterampilan dalam penelitian ini adalah keterampilan siswa saat melakukan praktikum dan membuat laporan praktikum terkait materi reaksi redoks di laboratorium. Indikator yang dinilai pada penilaian aspek keterampilan melakukan praktikum meliputi mengambil larutan dan menuangkan larutan, mengukur volume larutan dengan gelas ukur, mereaksikan larutan, disiplin kerja di laboratorium.

Indikator penilaian aspek keterampilan melalui pembuatan laporan praktikum meliputi kesesuaian laporan, penyajian data dan analisis data, keterampilan menyimpulkan, penyajian jawaban pertanyaan, kerapian dan kedisiplinan. Hasil ketercapaian dari observasi selama praktikum dan pembuatan laporan praktikum disajikan dalam Tabel 7 yang menunjukkan bahwa semua siswa mencapai target ketercapaian maksimum yaitu $100 \%$. Berdasarkan analisis hasil observasi aspek keterampilan siklus I dapat diketahui bahwa semua ketercapaian telah mencapai target.

\section{Tabel 7 Hasil Ketercapaian Aspek Keterampilan Siklus I}

\begin{tabular}{lccc}
\hline $\begin{array}{c}\text { Aspek } \\
\text { Keterampilan }\end{array}$ & $\begin{array}{c}\text { Target } \\
(\%)\end{array}$ & $\begin{array}{c}\text { Ketercapaian } \\
(\%)\end{array}$ & Kriteria \\
\hline Praktikum & 75 & 100 & Tercapai \\
Laporan & 75 & 100 & Tercapai \\
\hline
\end{tabular}

Hasil prestasi belajar pada penelitian ini dapat disimpulkan bahwa penerapan model pembelajaran inkuiri terbimbing dengan media LKS dapat meningkatkan prestasi belajar siswa. Penelitian ini sejalan dengan Setiowati (2015) [18] dan Kurniawati (2016) [20] pada hasil penelitiannya yang menyimpulkan bahwa penerapan model pembelajaran inkuiri terbimbing dilengkapi LKS dapat meningkatkan prestasi belajar siswa pada materi kelarutan dan hasil kelarutan dan materi hukum dasar kimia. Sedangkan hasil penelitian Azizah dan Indah (2014) menunjukkan bahwa keterlaksanaan model pembelajaran inkuiri terbimbing pada materi pokok larutan elektrolit dan non elektrolit pada pertemuan I dan II terlaksana sangat baik dengan persentase $82,8 \%$ dan $88,1 \%$ [21]. Menurut penelitian Sari (2016) penerapan Process Oriented Guided Inquiry Learning dilengkapi LKS dapat meningkatkan prestasi belajar sebesar $28,3 \%$ dengan perolehan pada siklus I sebesar $53,8 \%$ dan siklus II menjadi 82 , $1 \%$ pada materi larutan penyangga [15].

Di dalam proses pembelajarannya sesuai dengan teori belajar Ausubel yaitu pembelajaran yang bermakna dan teori belajar Bruner yaitu siswa berusaha sendiri secara aktif untuk memecahkan masalah sesuai dengan permasalahan tersebut melalui pengalaman, eksperimen dan interaksi dengan lingkungan, agar menemukan konsep itu 
sendiri. Hal ini dikarenakan siswa belajar secara aktif untuk menemukan sendiri konsep reaksi redoks, sehingga proses pembelajaran lebih bermakna dan siswa lebih memahami konsep tersebut. Pada penelitian Swandhana dkk (2016) menunjukkan strategi pembelajaran inkuiri terbimbing terbukti layak dan dapat meningkatkan hasil belajar dan kemandirian belajar siswa dengan kemandirian belajar siswa sebesar $90 \%$ [22].

\section{KESIMPULAN}

Berdasarkan hasil penelitian yang telah dilakukan, maka dapat diambil kesimpulan sebagai berikut:

Penerapan model pembelajaran inkuiri terbimbing dapat meningkatkan kemandirian siswa kelas X MIPA SMA Negeri 1 Teras Boyolali tahun pelajaran 2016/2017 semester genap pada materi reaksi redoks. Pada siklus I ketercapaian kemandirian belajar siswa sebesar $68,52 \%$ dan pada siklus II mengingkat menjadi $78,7 \%$. (2) Penerapan model pembelajaran inkuiri terbimbing dapat meningkatkan prestasi belajar pada materi reaksi redoks siswa kelas X MIPA SMA Negeri 1 Teras Boyolali tahun pelajaran 2016/2017 semester genap. Ditunjukkan dengan ketercapaian aspek pengetahuan pada siklus I sebesar $41,67 \%$ dan meningkat pada siklus II menjadi $63,89 \%$. Aspek sikap dan aspek keterampilan yang telah mencapai target pada siklus I yaitu dengan ketercapaian sebesar $90 \%$ untuk aspek sikap dan ketercapaian sebesar $100 \%$ untuk aspek keterampilan.

\section{UCAPAN TERIMA KASIH}

Penulis mengucapkan terima kasih kepada Drs. Wakimun selaku Kepala SMA Negeri 1 Teras Boyolali yang telah memberikan ijin penelitian Esti Putriyanti, S.Pd., Suparjono El. S.Pd., M.Pd., Drs. Arifin Trisanyoto, M.Eng., selaku guru mata pelajaran Kimia di SMA Negeri 1 Teras Boyolali yang telah membantu penulis dalam penelitian.

\section{DAFTAR RUJUKAN}

[1] Undang-Undang Dasar 1945

[2] Depdiknas, 2006, Peraturan Menteri Pendidikan Nasional Republik Indonesia Nomor 20 Tahun 2003 Tentang Sistem Pendidikan Nasional. Jakarta: Depdiknas

[3] Suyatno, Purwadi, Aris, Widayanto, Henang dan PR, Kuncoro. (2007). Kimia untuk SMA/MA Kelas $X$. Jakarta: Grasindo

[4] Anonim. Arsip daftar nilai UTS dan UAS Tahun Pelajaran 2016/2017 semester ganjil kelas $X$ MIPA 3 dan $X$ MIPA 4 SMA Negeri 1 Teras Boyolali

[5] Puspendik. Hasil Laporan Ujian Nasional SMA/MA Tahun Pelajaran 2014/2015. Diperoleh 2 Januari 2017 dari 118.98.234.50/lhun/

[6] Permendikbud. (2016). Salinan lampiran Peraturan Menteri Pendidikan dan Kebudayaan Nomor 24 Tahun 2016 tentang Kompetensi Isi dan Kompetensi Dasar. Jakarta: Kemendikbud.

[7] Joyce,B. R., and Weil, M. (2000). Models of Teaching and Learning: Where Do they Come From and How Are They Used? In Models of Teaching (6th ed., pp, 13-28). Allyn and Bacon

[8] Karyatin. (2013). Penerapan Pembelajaran Inkuiri Terbimbing Berbasis Laboratorium untuk Meningkatkan Keterampilan Proses dan Hasil Belajar IPA Siswa Kelas VIII-4 di SMPN 1 Probolinggo. JPK, 1 (2), 178-186

[9] Schwarz and Gwekwerere. (2006). Using a Guided Inquiry and Modeling Instructional Framework (EIMA) to Support Preservice K-8 Science Teaching. WIS DOI 10.1002/sce.20177 
[10] Villagonzalo, Erl C. (2014). Process Oriented Guided Inquiry Learning: An Effective Approach in Enhacing tudents Academic Performance. Philippines: The DLSU Reasearch Congress 2014

[11] Barthlow, M. J. (2011). The Effectiveness of Process Oriented Guided Inquiry Learning to Reduce Alternate Conceptions in Secondary Chemistry. Disertasi. Liberty University

[12] Arikunto, Suharsimi. (2012). Dasardasar Evaluasi Pendidikan. Jakarta: Bumi Akasara

[13] Miles, M.B. \& Huberman, A.M. (1995). Analisis Data Kualitatif. Jakarta: UI Press

[14] Moleong, L. J. (2010). Metodologi Penelitian Kualitatif. Bandung: PT Remaja Rosdakarya

[15] Sari, W. A., Saputro, A. N. C., dan Masykuri, M. (2016). Penerapan Pembelajaran Process Oriented Guided Inquiry Learning (POGIL) Dilengkapi LKS untuk Meningkatkan Kemandirian dan Prestasi Belajar Siswa. JPP, 3(2): 114-128.

[16] Pamungkas, Aprilia Suryaning. (2013). Peningkatan Kemandirian dan Hasil Belajar Matematika Melalui Strategi Inkuiri Terbimbing dalam Pokok Bahasan Teorema Phytagoras. Skripsi. UMS Surakarta

[17] Brown, S. D., (2010). A ProcessOriented Guided Inquiry Approach to Teaching Medicinal Chemistry. AJPE, 74 (7) Article 12
[18] Setiowati, H., Saputro, Agung Nugroho C. dan Setyowati, Widiastuti A. E. (2015). Penerapan Inkuiri Terbimbing Dilengkapi LKS untuk Meningkatkan Aktivitas dan Prestasi Belajar Siswa Pada Materi Kelarutan dan Hasil Kali Kelarutan Kelas XI MIA SMA Negeri 1 Banyudono Tahun Pelajaran 2014/2015. JPK, 4(4): 54-60

[19] Permendikbud. (2014). Salinan Lampiran Peraturan Menteri Pendidikan dan Kebudayaan Nomor 104 Tahun 2014. Jakarta: Kemendikbud

[20] Kurniawati, D. (2016). Penerapan Inkuiri Terbimbing Dilengkapi LKS untuk Meningkatkan Keterampilan Proses Sains dan Prestasi Belajar pada Materi Pokok Hukum Dasar Kimia Siswa Kelas X Mia 4 SMA N 1 Karanganyar Tahun Pelajaran 2014/2015. JPK, 5 (1): 88-95

[21] Azizah, Utiya dan Indah, Yenny Ayu Swara. (2014). Penerapan Model Pembelajaran Inkuiri Terbimbing dengan Pendekatan Saintifik (Scientific Approach) pada Materi Pokok Larutan Elektrolit dan Non Elektrolit Kelas X MIA 5 SMAN 3 Surabaya. Unesa Journal of Chemical Education, 3(3):105-111

[22] Swandhana, Churiyah, Kharisma, Madziatul dan Juariyah, Lohana. (2016). Meningkatkan Kemandirian Belajar dan hasil Belajar Siswa melalui Pengembangan Modul Administrasi Kepegawaian Berbasis Strategi Pembelajaran Inkuiri Terbimbing. JPBM, 2(3): 161-169 